УДК 614.2:616-053:615.371/.372

DOI 10.11603/2411-1597.2020.1.11036

\title{
СТАН ВАКЦИНАЦІЇ ДІТЕЙ У МІСТІ ГОРОХІВ ВОЛИНСЬКОЇ ОБЛАСТІ
}

\author{
Т. І. Толокова ${ }^{1}$, О. В. Гальчук ${ }^{2}$ \\ 1Тернопільський національний медичний університет \\ імені І. Я. Горбачевського МОЗ Украӥни \\ ${ }^{2}$ Горохівська центральна районна лікарня
}

У статті проаналізовано стан вакцинації дітей в м. Горохів Волинської області та визначено фактори, що формують ставлення батьків до щеплень.

\section{STATE OF VACCINATION IN CHILDREN IN HOROKHIV VOLYN REGION}

\author{
T. I. Tolokova ${ }^{1}$, O. V. Halchuk ${ }^{2}$ \\ 1I. Horbachevsky Ternopil National Medical University \\ ${ }^{2}$ Horokhiv Central District Hospital
}

The article analyzes the vaccination status of children in Horokhiv Volyn region and identifies factors that shape parents' attitudes toward vaccinations.

Вступ. За даними Всесвітньої організації охорони здоров'я (ВООЗ), інфекційні захворювання $є$ причиною смертності в 24,7 \% випадків, а серед дітей цей показник становить 63 \%. Завдяки заходам планової вакцинопрофілактики дітей із використанням високоефективних медичних імунобіологічних препаратів (МІБП) щороку вдається запобігти до 3 млн дитячих смертей від особливо небезпечних інфекцій. Саме тому експертами ВООЗ останнім часом приділяється особлива увага стану інфекційної захворюваності у світі, розробляються глобальні та регіональні програми з вакцинації, основні положення яких спрямовані на підвищення доступності МІБП для населення, збільшення рівня охоплення вакцинацією, введення нових МІБП до національних календарів профілактичних щеплень $[2,3,5,7]$.

Вищенаведене свідчить про надзвичайну актуальність проблеми запобігання епідемічній напруженості та узагальненню причин недостатньої відповідальності осіб, які приймають рішення щодо щеплення.

Мета роботи: проаналізувати стан вакцинації дітей в м. Горохів, визначити структуру факторів, що формують ставлення батьків до щеплень.

Основна частина. ВУкраїні забезпечення населення МІБП для планової вакцинації дітей здійснюється

() Т. І. Толокова, О. В. Гальчук, 2020 коштами державного бюджету з урахуванням термінів вакцинації, які визначено Національним календарем профілактичних щеплень. Однак, на жаль, останнім часом для вітчизняної галузі охорони здоров'я негативною тенденцією $є$ стрімке падіння рівня охоплення профілактичними щепленнями за кожною рекомендованою нозологією, що, зі свого боку, створює загрозу різкого зростання інфекційних захворювань. Отже, проведення різнобічних наукових досліджень щодо основних питань функціонування системи планової вакцинопрофілактики дітей $є$ одним із перших кроків реформування вітчизняної системи охорони здоров'я відповідно до міжнародного досвіду $[1,4,6]$. Однією із ланок ефективної діяльності цієї системи є висококваліфіковані медичні сестри, які безпосередньо контактують з батьками й впливають на формування довіри до медичної допомоги.

Більшість сучасного населення країни має недостатній рівень інформаційної забезпеченості щодо використання та дії вакцин, внаслідок чого відмовляється від такого дієвого способу профілактики смертельно небезпечних захворювань. На прикладі актуального стану вакцинації дітей м. Горохів авторами вивчено причини відмови батьків від вакцинації та ефективність проведення просвітницької роботи щодо важливості запобігання соціально загрозливим

32 ISSN 2411-1597. МЕДСЕСТРИНСТВО. 2020. № 1 
захворюванням серед різних верств населення, що дозволить полегшити діяльність медичних працівників та оптимізує профілактичну роботу з метою запобігання смертельно небезпечним хворобам.

За даними дитячої поліклініки м. Горохів, медичні заклади міста отримують вакцини як обов'язкові, так і рекомендовані, відповідно до орієнтовних термінів постачання вакцин, що закуповуються Дитячим фондом ООН ЮНІСЕФ у рамках закупівель лікарських засобів за замовленням Міністерства охорони здоров'я України.

Протягом 2015-2018 рр. забезпечення вакцинами було не систематичним. За останнє півріччя ситуація налагодилась та почались поставки вакцин не лише вітчизняних виробників (Харківського фармацевтичного заводу), але і закордонних (Франція, Бельгія, Індія, Корея, Китай) [6].

Відповідно до результатів аналізу стану вакцинації в дитячій поліклініці м. Горохів Волинської області, з'ясовано, що більшість дітей не отримала необхідних щеплень через відмову батьків (табл. 1), при цьому частина батьків не заперечує вакцинації, однак перш ніж імунізувати дитину вони ознайомлюються з відомостями про постачальника та якість препарату. Кількість інформованих відмов свідчить про недовіру батьків до вакцин, які пропонують заклади охорони здоров'я.

\section{Табличя 1. Статистика вакцинованих дітей м. Горохів (станом на 1 січня 2018 р.)}

\begin{tabular}{|l|c|l|c|c|}
\hline Вікова категорія & Усього дітей & Вакциноване захворювання & Кількість вакцинованих & Частина (\%) \\
\hline \multirow{3}{*}{ До 1 року } & \multirow{2}{*}{424} & дифтерія & 82 & 19,44 \\
\cline { 3 - 5 } & & гепатит В & 226 & 35,30 \\
\cline { 3 - 5 } & & поліомієліт & 128 & 30,19 \\
\cline { 3 - 5 } & & гемофільна інфекція & 55 & 12,97 \\
\cline { 3 - 5 } & & КПК & 351 & 82,78 \\
\hline 6 років & 394 & КПК & 266 & 67,51 \\
\hline 7 років & 211 & КПК & 137 & 19,76 \\
\hline 14 років & 339 & дифтерія & 67 & 19 \\
\hline
\end{tabular}

Отримані результати свідчать, що частка вакцинованих дітей досить низька й недостатня для формування колективного імунітету. Причиною реальної напруженої епідемічної ситуації $є$ відмова батьків від вакцинації, що спричинено рядом обставин: поперше - недовірою до виробника вакцини, по-друге - небажанням вводити «віруси» в організм дитини через низьку обізнаність з питань вакцинації.

Нами розроблено анкету та проведено соціологічне опитування, в якому взяло участь 120 осіб, батьків дітей віком 1-18 років. Опитуваних поділили на 2 групи: 1-ша - мали позитивне ставлення до щеплень (76 респондентів - 63,3 \%); 2-га - негативно ставились до вакцинації (44 респондента - 36,7 \%). Діти цих батьків були щеплені/або не отримували щеплення. При цьому частка дітей, які не отримували щеплення або щеплені лише в пологовому будинку, значно вища у 2-й групі респондентів.

Результати опитування показали, що 41,9 \% серед респондентів, які мають позитивне ставлення до вакцинації, та 70,3 \% серед тих, які мають негативне ставлення до вакцинації, обирають індивідуальний календар щеплень, тобто вважають припустимими лише певні щеплення, які вважають за потрібне.
На питання «Проти яких хвороб Ви вважаєте за необхідне проводити щеплення дітям?», найбільша кількість респондентів (21 \%) обрала кашлюк, проти краснухи та гепатиту згодні робити щеплення по 17 \% опитаних, і лише 4 \% вважають за необхідне робити щеплення проти поліомієліту та лише $10 \%$ не проти проби Манту, що пов'язано з неодноразовими повідомленнями в засобах масової інформації про ускладнення, які виникають після цих щеплень.

Респондентам, які мали негативне ставлення до вакцинації, запропоновано обрати одну з найвірогідніших причин, що вплинули на формування у них такого ставлення. Серед опитаних 37 батьків (30,8 \%) мають страх від ускладнень, що можуть спричинити щеплення. Відмова 18 осіб (15\%) від такої процедури пов'язана з негативною інформацією, почутою в засобах масової інформації чи від знайомих. 12 (10\%) вважають, що щеплення послаблюють імунітет, і стільки ж погоджуються, що їх дійсно робити немає сенсу. 5,8 \%, а саме 7 респондентів, мають власний негативний досвід від результату щеплень, а 2 людини не розуміють, для чого здійснювати вакцинацію, вважаючи, що вона не потрібна, оскільки інфекції, від яких роблять щеплення, трапляються не часто, 
або вважають, що вони шкодять духовному та психічному розвитку дитини.

Опитування показало, що всі респонденти плутають поняття «поствакцинальна реакція» і «поствакцинальне ускладнення», не знають, які стани можуть бути ускладненнями вакцинації, а які цілком закономірною реакцією на щеплення. Значна частина 78 (65 \%) опитаних не ознайомлені з рекомендованим календарем щеплень і тому вважають, що тих щеплень, які роблять дитині ще в пологовому будинку, цілком достатньо. У 85 (70,8 \%) анкет виявлено перебільшення вірогідності виникнення поствакцинальних ускладнень, що підтверджує актуальність обраної теми дослідження та необхідність посилення просвітницької, роз'яснювальної роботи серед батьків із даних вищеозначеної проблематики.

Опитування виявило низьку довіру до роз'яснень медичного персоналу, а саме 63 \% батьків більше довіряють інформації, яку отримали від родичів, знайомих, із засобів масової інформації, інтернету, ніж порадам лікаря та медичної сестри, і лише 37 \% батьків прислухались до порад медиків при прийнятті рішення щодо щеплень дитини.

Висновки. Ставлення українців до профілактичних щеплень значною мірою зумовлено впливом засобів

\section{СПИСОК ЛІТЕРАТУРИ}

1. Абатуров А. Е. Значение медико-социальных факторов в формировании отношения родителей к иммунопрофилактике / А. Е. Абатуров, Е. А. Агафонова, О. В. Седунова // Журнал «Здоровье ребенка». - 2013. № 7 (50). - С. 37-42.

2. Кононенко О. Порівняльний аналіз медико-соціальних підходів до проведення планової імунізації населення у вітчизняній та закордонній практиці / О. Кононенко // Матеріали XVIII Міжнародного медичного конгресу студентів та молодих вчених, м. Тернопіль, 28-30 квіт. 2014 р. - Тернопіль : Укрмедкнига, 2014. - С. 83.

3. Котвіцька А. А. Аналіз стану охоплення профілактичними щепленнями проти керованих інфекційних захворювань та рівня інфекційної захворюваності в Україні / А. А. Котвіцька, О. В. Кононенко // Актуальні проблеми розвитку галузевої економіки та логістики : матеріали IV Міжнародної науково-практичної конференції, м. Харків, 2-3 квіт. 2015 р. - Х. : НФаУ, 2015. - С. 264-265. масової інформації та суспільною думкою знайомих і друзів, ніж порадами фахівців. Відповідно, більшість батьків недостатньо обізнані щодо потрібності щеплень, але дуже бояться ускладнень від них. Страх батьків ґрунтується на незнанні, низькій грамотності, перебільшенні поствакцинальних ускладнень та частково - безпечності «навіщо робити щеплення проти хвороб, які в Україні трапляються рідко».

Оскільки за здоров'я дитини відповідають їі батьки, а не лікарі, медсестри чи журналісти, які доволі часто оприлюднюють суперечливі дані, вважаємо, що знання - то найкраще озброєння у протидії соціально небезпечним захворюванням. На жаль, жоден медичний працівник, журналіст чи інші порадники не можуть гарантувати, що в своєму житті дитина не контактуватиме зі збудниками того чи іншого захворювання, від якого можна убезпечитись, виконуючи щеплення. Тому агітаційно-роз'яснювальна робота, яку професійно проводять лікарі та медичні сестри, передбачає необхідність вивчення інформаційної бази про інфекційні хвороби та вакцинацію. Отже, набуває особливої актуальності безперервна освіта середнього медичного персоналу в сфері обізнаності щодо вакцинації населення.

4. Лобзин Ю. В. Проблема вакцинопрофилактики: краткая история, современное состояние и пути решения / Ю. В. Лобзин, С. М. Харит // Эпидемиология и инфекционные болезни. - 2014. - № 6. - С. 30-37.

5. Оптимізація проведення планових щеплень дітей, що часто хворіють / А. Ю. Волянський, О. А. Романова, Т.В.Давидова, К. С. Конорєва // Аннали Мечниковського інституту. - 2012. - № 4. - С. 189-190.

6. Устінов О. В. Вакцинація за віком, стан колективного імунітету та антивакцинальні кампанії: сучасна ситуація в Україні / О. В. Устінов, Д. Чудутова // Український медичний часопис. - 2018. - № 4 (89). - С. 33-36.

7. Is there a place for the patient in the Ukrainian health care system? Patient payment policies and investment priorities in health care in Ukraine / A. Danyliv, T. Stepurko, I. Gryga [et al.] // Society and Economy. - 2012. - Vol. 34 (2). P. 273-291. 